\title{
Ultrasound-assisted production of biodiesel FAME from rapeseed oil in a novel two- compartment reactor
}

Nakayama, Ryo-ichi; Imai, Masanao; Woodley, John

Published in:

Journal of Chemical Technology and Biotechnology

Link to article, DOI:

$10.1002 /$ jctb. 5047

Publication date:

2017

Document Version

Peer reviewed version

Link back to DTU Orbit

Citation (APA):

Nakayama, R., Imai, M., \& Woodley, J. (2017). Ultrasound-assisted production of biodiesel FAME from rapeseed oil in a novel two-compartment reactor. Journal of Chemical Technology and Biotechnology, 92(3), 657-665. https://doi.org/10.1002/jctb.5047

\section{General rights}

Copyright and moral rights for the publications made accessible in the public portal are retained by the authors and/or other copyright owners and it is a condition of accessing publications that users recognise and abide by the legal requirements associated with these rights.

- Users may download and print one copy of any publication from the public portal for the purpose of private study or research.

- You may not further distribute the material or use it for any profit-making activity or commercial gain

- You may freely distribute the URL identifying the publication in the public portal 
Ultrasound-assisted production of biodiesel FAME from rapeseed oil in a novel

\section{two-compartment reactor}

\section{Authors}

Ryo-ichi Nakayama, ${ }^{\mathrm{a} \dagger}$ Masanao Imai, ${ }^{\mathrm{a}^{*}}$ and John M. Woodley ${ }^{\mathrm{b}}$

\section{Address}

${ }^{a}$ Course in Bioresource Utilization Sciences, Graduate School of Bioresource Sciences, Nihon University, 1866 Kameino, Fujisawa, Kanagawa Pref., 252-0880 Japan

${ }^{\mathrm{b}}$ Department of Chemical and Biochemical Engineering, Technical University of Denmark, DK-2800 Kgs. Lyngby, Denmark

* Correspondence to: Professor Masanao Imai, Course in Bioresource Utilization Sciences, Graduate School of Bioresource Sciences, Nihon University, 1866 Kameino, Fujisawa, Kanagawa pref., 252-0880 Japan, E-mail: XLT05104@nifty.com, Phone: +81-466-84-3978,

Fax: +81-466-84-3978

${ }^{\dagger}$ Present Address : Department of Environmental Chemistry and Chemical Engineering, School of Advanced Engineering, Kogakuin University, 2665-1 Nakano-machi, Hachioji, Tokyo, 192-0015, Japan

\section{Abstract}

BACKGROUND: Ultrasonication has been proposed as a promising technique for enzymatic transesterification. In contrast, excess ultrasonication causes an enzyme inactivation. This paper presents enzymatic transesterification to produce fatty acid methyl ester (FAME) from

This article has been accepted for publication and undergone full peer review but has not been through the copyediting, typesetting, pagination and proofreading process, which may lead to differences between this version and the Version of Record. Please cite this article as doi: $10.1002 /$ jctb.5047 
rapeseed oil using Callera Trans $\mathrm{L}^{\mathrm{TM}}$ using a an original two-compartment reactor. The reactor was composed of a mechanically stirred compartment (ST) and ultrasound irradiation compartment (US). The reaction solution was recirculated between the ST and the US. The enzyme was only exposed by ultrasonication in the US. The reactor system has the option to control the direct irradiation period of ultrasonication to soluble enzyme, regulated by the mean residence time in the US.

RESULTS: The production of FAME with ultrasound irradiation gave a final yield of $91 \mathrm{wt} \%$ after 15hours. The reaction rate was enhanced up to 2-fold through the use of the two-compartment reactor compared with liquid lipase catalyzed transesterification without any ultrasound treatment. The $V_{\max }$ with the ultrasound irradiation was 2.3-fold higher than that of the ultrasound free system, while the $K_{m}$ remained at almost the same level. The reaction rate and the conversion increased with a shorter mean residence time in the US.

CONCLUSION: The excellent advantages of the two-compartment reactor were presented to produce biodiesel (FAME) resulting in acceleration of the enzyme reaction by ultrasound irradiation. Especially, reaction enhancement was maximally obtained using a separate compartment of the reactor. A shorter mean residence time of reaction solution in the US and higher ultrasound power successfully realized a higher production rate of FAME.

This article is protected by copyright. All rights reserved. 
Keywords: Biodiesel, Lipase, Ultrasound, Transesterification, Rapeseed oil

\section{INTRODUCTION}

Biodiesel has emerged as an environmentally-friendly and renewable alternative fuel. The

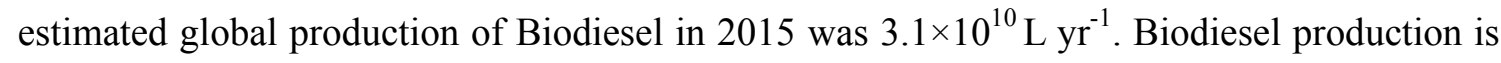
estimated to increase to $11 \times 10^{10} \mathrm{~L} \mathrm{yr}^{-1}$ by $2020 .{ }^{1}$ Biodiesel is produced from triglycerides by transesterification with short chain alcohols (Figure 1). ${ }^{2,3}$ Alkaline catalysis has often been employed in the industrial production of biodiesel, although it requires excess alkaline loading and results in environmental problems involving waste disposal. ${ }^{4-6}$.

In the last decade an alternative enzymatic process using a lipase enzyme has been suggested to catalyze the transesterification because it has the advantage of being able to convert low-grade feed-stocks with high free fatty acid (FFA) content, resulting in significant economic as well as environmental benefits. ${ }^{7,8}$ In order to keep the cost of the enzyme low enough at first researchers attempted to recycle the enzyme, aided by immobilization. ${ }^{9-12}$ Nevertheless, despite some success it has subsequently become clear that the use of soluble (liquid) enzyme comes at a lower cost contribution to the final product and results in 
significant process simplification. Today the use of liquid lipase for the transesterification in the presence of free fatty acids has been reported scientifically and commercially demonstrated. ${ }^{13-15}$

Several scientific publications attest to the clear advantages of such a system catalyzed by Callera Trans $\mathrm{L}^{\mathrm{TM}}$, a liquid lipase formulation from Thermomyces lanuginosus (Novozymes A/S, Denmark). ${ }^{16}$

From previous studies it is known that the lipase from Thermomyces lanuginosus has high catalytic activity for the transesterification reaction. ${ }^{17-19}$ Conventionally, in order to make use of this enzyme activity, and since the enzyme is interfacially-activated the aqueous-organic interface has been made as large as possible by mechanical stirring, using a well agitated stirred tank. This is a considerable cost for a commercial process, even at moderate power inputs per unit volume of reaction solution.

More recently ultrasound irradiation has been proposed as a useful technique to accelerate transesterification reactions. $^{20-25}$ Reports suggest that using ultrasound energy can considerably intensify the process by generating cavitation in the reaction liquid phase. ${ }^{26,27}$ Cavities subsequently grow and finally collapsed, releasing a large amount of energy in a small volume of solution. ${ }^{28}$ As a result, the very high density of energy influences mass transfer between different phases $^{29}$, and potentially the enzyme also. Previous investigations on the use of ultrasound energy for biodiesel production with enzymes has been published. Table 1 lists other types of lipase used in enzymatic transesterification assisted by ultrasound 
irradiation. ${ }^{30-35}$ The results indicate that ultrasound irradiation would create an effective micro-scaled interfacial area where lipid and lipase react in a biodiesel process.

In this paper, we present a two-compartment reactor system using ultrasound irradiation to enhance the enzyme reactivity. The two reactor compartments are connected by a recirculation loop and are organized to allow the benefit of ultrasound irradiation on productivity of enzyme reaction, while minimizing exposure.

\section{EXPERIMENTAL}

\section{Materials}

Rapeseed oil was obtained from Emmelev A/S (Otterup, Denmark). Methanol (99.8\%, technical grade) was purchased from VWR Bie \& Berntsen A/S (Herlev, Denmark). Table 2 shows the properties of refined oil used in this study. Acetic acid (99\%), n-heptane (99\%), isopropanol (99\%), and tert-butyl methyl ether (99.8\%) were obtained from Sigma-Aldrich A/S (Brøndby, Denmark). Enzymatic reactions were carried out using soluble lipase (Callera $\mathrm{L}^{\mathrm{TM}}$ ), which was kindly donated by Novozymes A/S (Bagsværd, Denmark). The activity of the enzyme was reported as approximately $1 \times 10^{5} \mathrm{U} / \mathrm{g}$-original liq., where $1 \mathrm{U}$ was defined as the activity required to produce $1 \mu \mathrm{mol}$ butyric acid from the hydrolysis of tributyrin under standard conditions ( $\mathrm{pH} 7.5,0.2 \mathrm{M}$ substrate).$^{36}$

\section{Recycle mode}

This article is protected by copyright. All rights reserved. 
Figure 2 presents a schematic diagram of the two-compartment reactor. One compartment is termed the "stirred compartment (ST)", and the other termed the "ultrasound compartment (US)". The ultrasonic horn was not installed at the deepest location in the US cell, since the glass made bottom of the US cell was mechanically damaged by direct irradiation of ultrasonication. Therefore, the ultrasonic horn was installed at the $2 \mathrm{~cm}$ depth from the top of the liquid level for safety reactions. The reaction fluid was then introduced to the top of the US cell in which nearby the ultrasonic horn was placed, as illustrated in Figure 2.

The ST compartment was made of a cylindrical glass. The initial reaction volume was $267 \mathrm{~mL}$ while rapeseed oil $220 \mathrm{~mL}$, initial methanol $25 \mathrm{~mL}$, and enzyme solution $22 \mathrm{~mL}$.The volume of recycle loop was in total $40 \mathrm{~mL}$. The inside diameter of ST compartment was $5.5 \mathrm{~cm}$. Mean depth of reaction solution in ST compartment at steady state was $5.4 \mathrm{~cm}$. Two baffle plates (1 cm width) were attached on inside lateral of ST compartment. A $2.4 \mathrm{~cm}$ diameter six-blade rushton turbine impeller was installed in the ST compartment and spun at $1400 \mathrm{~min}^{-1}$. Two baffles $(1 \mathrm{~cm}$ width) were attached on the inside lateral of the ST compartment. The ST compartment was immersed in a water bath $(308 \mathrm{~K})$. The temperature was controlled by equipment from Julabo Labor-technik GmbH; (Seelbach, Germany).

The effective liquid volume in US compartment (glass flow cell) in steady state was $80 \mathrm{~mL}$. the ultrasound irradiation device was inserted inside this and supplied by GD14K (Hielscher Ultrasonic GmbH, Germany). Ultrasonic irradiation at a frequency of $24 \mathrm{kHz}$ was directly provided into reaction solution using a horn-shaped cylindrical device UP200S. The diameter 
$\varphi$ of the device was $14 \mathrm{~mm}$. The cross sectional area of the ultrasonic horn was $153 \mathrm{~mm}^{2}$. The guaranteed high surface power density was $1.25 \mathrm{~W} \mathrm{~mm} \mathrm{~m}^{-2}$. That can be controlled at 20,40 , and $60 \%$ of maximum. The applied ultrasound output was therefore calculated as 38,77 and $115 \mathrm{~W}$, respectively. The temperature in the US compartment was maintained at $308 \mathrm{~K}$ by a water jacket. It was regulated by a Thermo DC10 (Thermo HAAKE, USA).

The two compartments (ST and US) were connected by a recirculation flow that was adjusted using a Watson MARLOW 520S. The recirculation flow rate $\left(F\left[\mathrm{~mL} \mathrm{~s}^{1}\right]\right)$ varied from 0.17 to $1.67 \mathrm{~mL} \mathrm{~s}^{-1}$. The mean residence time of the reaction solution in the US $(\theta[\mathrm{s}])$ calculated by the volume of US reactor vessel $\left(V_{U}[\mathrm{~mL}]\right)$, which was $80 \mathrm{~mL}$, divided by the recirculation flow rate as Eq. (1).

$$
\theta=\frac{V_{U}}{F}
$$

The volume of the connected recirculation loop $\left(V_{L}[\mathrm{~mL}]\right)$ between the ST and the US was $40 \mathrm{~mL}$. The initial volume of ST solution $\left(V_{S}[\mathrm{~mL}]\right)$ was $267 \mathrm{~mL}$. Therefore, the overall circulation time $(\Theta[\mathrm{s}])$ throughout US, ST and recirculation loop was calculated by Eq. (2).

$$
\Theta=\frac{V_{U}+V_{S}+V_{L}}{F}
$$

Table 3 presents details of recirculation conditions in the reactor system. In this work, the ratio of residence time of US to the overall reaction line $(\theta / \Theta)$ was constant at 0.21 .

Rapeseed oil $(220 \mathrm{~mL})$ was used as a substrate for the reaction. $2 \mathrm{~g}$ of lipase solution was dissolved in $20 \mathrm{~g}$ of distilled water. The concentration of enzyme based on the mass fraction is therefore 0.09 [g-enzyme $\cdot \mathrm{g}^{-1}-($ enzyme + water $)$ ] and used throughout this paper. $\mathrm{n}$-Heptane 
was employed as an inert component in the organic phase to prepare the desired concentration of substrate. The substrate concentration varied from 0.23 to 0.9 [g-oil $\cdot \mathrm{g}^{-1}$ - (oil + n-heptane + methanol)].

The US was initially empty. Methanol $(25 \mathrm{~mL})$ was initially added to the rapeseed oil in the ST before the reaction. The enzyme aqueous solution $(22 \mathrm{~mL})$ was then added to the rapeseed oil and methanol mixture. The reaction was initiated by adding enzyme, and the recirculation flow between the ST and the US was simultaneously started.

After the initiation of the reaction, methanol was continuously fed $\left(50 \mu \mathrm{L} \mathrm{s}^{-1}\right)$ into the ST. Methanol addition was a useful technique to obtain a higher yield of biodiesel according to our previous experience. The methanol was introduced using a KNF STEPODS. 03 pump (KNF Neuberger AB, Stockholm. Sweden).

Ultrasound irradiation was initiated when the volume of reaction solution in the US became stable at $80 \mathrm{~mL}$ at the steady state. The recirculation flow rate was monitored and regulated to keep the volume of reaction solution in the US at $80 \mathrm{~mL}$ throughout the reaction.

\section{Sample preparation and analysis by high-performance liquid chromatography}

$50 \mu \mathrm{L}$ samples were periodically taken from the ST and then mixed with $500 \mu \mathrm{L}$ solvent A $(99.6 \%(\mathrm{v} / \mathrm{v}) \mathrm{n}$-heptane and $0.4 \%(\mathrm{v} / \mathrm{v})$ acetic acid). The mixed sample was centrifuged at $14500 \mathrm{rpm}$ for $5 \mathrm{~min}$, and then $10 \mu \mathrm{L}$ of supernatant was mixed with $990 \mu \mathrm{L}$ of solvent A before high-performance liquid chromatography (HPLC) analysis. 
$40 \mu \mathrm{L}$ of the above sample was injected into an HPLC system (Ultimate 3000, Dionex A/S,

Hvidovre, Denmark). The HPLC was employed to measure the concentration of triglyceride (TAG), diglyceride (DAG), monoglyceride (MAG), free fatty acid (FFA), and fatty acid methyl ester (FAME). These five compounds were separated using a cyanopropyl column $(0.25 \times 0.004 m)\left(\right.$ Discovery ${ }^{\circ}$, Cyano, Sigma Aldrich A/S, Brøndby, Denmark), a U3000 auto sampler, a TCC-3000SD column oven, U3400A quaternary pump modules, and a CoronaR Charged Aerosol Detector (Thermo Scientific Dionex, Chelmsford, MA, USA).

A binary gradient program was employed to separate the five different compounds using solvent A, solvent B (99.6\% (v/v) tert-butyl methyl ether and $0.4 \%(\mathrm{v} / \mathrm{v})$ acetic acid), and solvent C (iso-propanol). The compounds were detected after separation with the column using a CoronaR Charged Aerosol Detector from Thermo Scientific Dionex (Chelmsford, MA, USA) with nitrogen gas at a pressure of $241 \mathrm{kPa}$.

\section{RESULTS and DISCUSSION}

\section{Effect of ultrasound on production of FAME}

In this work, fatty acid methyl ester (FAME) was measured as a main component of biodiesel. In Table 4, molecular weight and density of the component reaction fluid was presented. The mass fraction of FAME in the reaction solution was employed as an indication of the reaction progress of biodiesel production. 


$$
\begin{aligned}
& \text { Name of component }[\text { Mass\%] } \\
& =\frac{\text { Mass of each compartmet at desired running time }[\mathrm{g}]}{\text { Total mass of each component at the initial condition }(\mathrm{TAG}[\mathrm{g}]+\mathrm{DAG}[\mathrm{g}]+\mathrm{MAG}[\mathrm{g}]+\mathrm{FFA}[\mathrm{g}]+\mathrm{FAME}[\mathrm{g}])} \times 100
\end{aligned}
$$

Figure 3 depicts the time course a typical transesterification reaction using liquid lipase. The concentration of TAG, DAG, MAG, and FAME monitored during 24h of the reaction. FAME was produced by transesterification of TAG with methanol with the aid of lipase. The transesterification is a sequence of three consecutive steps. In the first step, TAG is converted to DAG. In the second step, DAG is converted to MAG. In the third step, MAG is converted to FFA. Each conversion step yields one FAME molecule, given a total of three FAME molecules per one TAG molecule. Fig. 3(a) shows the effect of ultrasound irradiation on the time course of the concentration of TAG. The concentration of TAG decreased evidently faster especially in the initial $1 \mathrm{~h}$ by ultrasound irradiation. In the case of intermediates (DAG and MAG) in Fig. 3(b) and (c), the peak time of DAG and MAG was also accelerated by ultrasound. In this manuscript, the purity of FAME was indicated as the mass fraction of FAME in reaction fluid. The final mass fraction of FAME achieved over $90 \mathrm{wt} \%$ at $15 \mathrm{~h}$ for ultrasound treatment $($ Fig.3 (d)). In contrast, $24 \mathrm{~h}$ was needed in the system without any ultrasound treatment to give the same yield. Accelerated production was evidently realized by ultrasonic treatment compare with no treatment. The cause of reaction enhancement by ultrasound irradiation is speculated to be that cavitation caused by the ultrasound induced micro-scale turbulence and that the mass transfer resistance was eliminated. ${ }^{37-39}$ Previous reports have suggested that ultrasound could cause the enzyme structure to become flexible; 
thus, the enzyme might shift into its active configuration. ${ }^{40}$

In order to understand further the origin of this enhancement a study of reaction kinetics was undertaken. Figure 4 presents the results of a kinetic experiment measuring reaction rate as a function of substrate concentration ranging from 0.23 to 0.9 [g-oil $\cdot \mathrm{g}^{-1}-($ oil $+\mathrm{n}$-heptane + methanol)]. In this study, n-heptane was employed as an inert solvent because of the need to evaluate the process at different substrate concentrations. As expected, the initial reaction rate increased with increasing substrate concentration.

The kinetic parameters were conveniently determined by a Hanes Woolf plot (Figure 5). The maximum reaction rate $V_{\max }$ with the ultrasound irradiation system was 2.3 -fold higher than that of the ultrasound free system, but interestingly the $K_{m}$ remained at almost the same level (Table 5). An increase in $V_{\max }$ seems to indicate that a considerable movement of reactants to the active site of the enzyme and the reaction products to the medium were achieved under the influence of the ultrasonic field. ${ }^{41}$

\section{Changing ultrasound power}

Figure 6 shows the effect of ultrasound power on the initial reaction rate, which increased with increasing ultrasound power. This clear demonstrates the positive effect of ultrasound irradiation in accelerating the reaction. With an increase in the ultrasound power, the number of cavitation bubbles also increases giving strong effect by catitation. ${ }^{42,43}$ The initial reaction rate of mean residence time of 470 s showed that the downward trend after over $77 \mathrm{~W}$. It is 
important to note here that further increase in treatment time caused harmful effects, as continuous exposure to cavitating conditions for prolonged time led to degradation of the amino acid residues which contributes to the substrate binding domain or catalytic domain of the enzyme molecules resulting in decrease in enzyme stability. ${ }^{44}$ This is the real advantage of the two compartment reactor to control the exposure time to ultrasound.

The ultrasonic irradiation for a reaction solution in short period of $48 \mathrm{~s}$ and $96 \mathrm{~s}$ was effective to enhance enzymatic initial reaction rate even in the higher power case of $115 \mathrm{~W}$. In contrast, longer continuous irradiation of ultrasonic power even in the lower ultrasonic power cased unexpected damage of enzyme activity. In our results, the irradiation period $470 \mathrm{~s}$ resulted lower initial reaction rate than that of other shorter period cases (48s and 96s) in our experimental range of ultrasound power. The cavitation during ultrasound irradiation induced oscillation by stable cavitation bubbles, that changes the spatial conformation of enzyme. ${ }^{45}$

Even if same accumulated time of ultrasonic irradiation, periodic shorter intermittent residence in the US compartment was strategically excelling mode to enhance initial reaction rate and to minimize damage of enzyme activity, as illustrated in Figure 7. Molecular structure damaged of enzyme well recovered in isolated period just after exposure period in the US. Longer period of exposure of high intensity ultrasound resulted in an unexpected inhibition to the catalytic activity of enzyme. On the other hands, shorter exposure of ultrasound attractively increased the activities of enzymes. ${ }^{46}$ It can be inferred that ultrasound brings the conformational change of enzyme. Higher oscillated frequency of irradiation and 
isolation periods, illustrated in Fig. 7 (b), proposed the high frequent opportunity for enzyme re-activation and refolding of molecular structure of enzyme. Further detail investigation needed to establish optimal irradiation manner for enzyme.

Figure 8 shows the effect of ultrasound power on the produced mass fraction of FAME with different mean residence time in the US. For mean residence time of $48 \mathrm{~s}$ and $96 \mathrm{~s}$, the maximum mass fraction of FAME appeared at $77 \mathrm{~W}$. The mass fraction of FAME obtained at $24 \mathrm{~h}$ indicated the maximum at $77 \mathrm{~W}$ for residence time $48 \mathrm{~s}$ and $96 \mathrm{~s}$. It was lower at power inputs above $77 \mathrm{~W}$ regardless of higher initial reaction rate. Ultrasound irradiation, under these extreme conditions, could cause great damage to polypeptide chains, leading to inactivation of the enzyme. ${ }^{47}$ In the case of residence time of 470 s, it was slightly decayed with increasing ultrasound power. According to our results, residence time less than 96s and ultrasonic irradiation power indicated an optimal condition for high initial reaction rate and mass fraction of FAME at $24 \mathrm{~h}$ in reaction solution.

The ultrasound energy applied to the enzyme seemed too large to disrupt the function of enzyme. ${ }^{48-50}$ Further investigation on the change of molecular structure especially nearby active site of the enzyme during ultrasound irradiation was necessary to determine an optimal residence time in US in conjunction with the irradiation power of ultrasound.

\section{Changing flow rate}

Figure 9 shows the effect of the space velocity of the reaction solution in the ultrasound 
compartment. The space velocity is the reciprocal of the mean residence time $(\theta[\mathrm{s}])$.

$$
\text { space velocity }\left[s^{-1}\right]=\frac{1}{\theta}
$$

As seen in the figure, the initial reaction rate increased with increasing space velocity under constant ultrasound power $(38 \mathrm{~W})$. It is speculated that the attractive association between enzyme and substrate was facilitated by micro-scaled cavitation caused by ultrasound irradiation. Enhancement of the reaction rate was previously reported for lipase reactions. ${ }^{51-53}$

Figure 10 indicates the effect of exposing the enzyme to ultrasound energy on the initial reaction rate. The ultrasound energy is calculated by the following equation.

$$
\text { ultrasound energy exposed to enzyme }[]] \text { = irradiated ultrasound power [W] X mean residence time in ultrasound compartment [s] }
$$

The initial reaction rate decreased as -0.3 power of the ultrasound energy exposed to enzyme. It is speculated that this occurred because the ultrasound irradiation accelerated the biodiesel reaction and maintained the enzyme activity due to the higher circulation flow rate.

\section{CONCLUSIONS}

Biodiesel (FAME) was successfully produced using a two-compartment reactor with optimal exposure to ultrasound balancing enhancement with suppression of enzyme damage. Enzymatic production of biodiesel by ultrasound irradiation was achieved with the reactor. The reaction rate was increased by ultrasound irradiation. The FAME yield was over $90 \mathrm{wt} \%$. In particular reactions with ultrasound treatment reached equilibrium faster than with no treatment. A shorter mean residence time and higher ultrasound power in the ultrasound 
compartment realized higher initial reaction rate of FAME production.

\section{Nomenclature}

$F$ : volumetric circulating flow rate $\left[\mathrm{mL} \mathrm{s}^{-1}\right]$

$K_{m}$ : Michaelis constant [g-oil $\mathrm{g}^{-1}-(\mathrm{oil}+\mathrm{n}-$ heptane+methanol $\left.)\right]$

[S]: substrate concentration [g-oil g ${ }^{-1}-($ oil + n-heptane + methanol)]

$V_{i}$ : initial reaction rate $\left[\mathrm{g}-\mathrm{FAME}(\mathrm{g}-(\mathrm{oil}+\mathrm{n}-\mathrm{h} \text { eptane }+ \text { methanol }) \cdot \mathrm{s})^{-1}\right]$

$V_{L}$ : volume of the connected recirculation loop $40 \mathrm{~mL}$

$V_{\max }:$ maximum reaction rate $\left[\mathrm{g}-\mathrm{FAME}(\mathrm{g}-(\mathrm{oil}+\mathrm{n}-\mathrm{heptane}+\text { methanol }) \cdot \mathrm{s})^{-1}\right]$

$V_{S}$ : initial volume of ST solution $267 \mathrm{~mL}$

$V_{U}$ : volume of US reactor vessel $80 \mathrm{~mL}$

\section{Greek symbols}

$\theta$ : mean residence time of the reaction solution in the US [s]

$\theta^{-1}$ : space velocity of the reaction solution in the US $\left[\mathrm{s}^{-1}\right]$

$\Theta$ : overall circulation time of reaction line (US+ ST+ recirculation loop) [s]

$\varphi$ : diameter of ultrasonic device (cylindrical shape) $[\mathrm{mm}]$

\section{Abbreviations}

This article is protected by copyright. All rights reserved. 
DAG: diacylglyceride

FAME: fatty acid methyl ester, biodiesel

FFA: free fatty acid

MeOH: methanol

ST: stirred compartment

TAG: triacylgylceride

US: ultrasound irradiation compartment

\section{REFERENCES}

1. Okoye PU and Hameed BH, Review on recent progress in catalytic carboxylation and acetylation of glycerol as a byproduct of biodiesel production, Renewable and Sustainable Energy Reviews 53: 558-574 (2016).

2. Demirbas A, Progress and recent trends in biofuels, Progress in Energy and Combustion Science 33: 1-18 (2007).

3. Meher LC, Sagar DV and Naik SN, Technical aspects of biodiesel production by transesterification-a review, Renewable and Sustainable Energy Reviews 10: 248-268 (2006).

4. Freedman B, PRYDE EH and Mounts TL, Variables affecting the yields of fatty esters from transesterified vegetable oils, Journal of the American Oil Chemists' Society 61: 1638-1643 (1984). 
5. Akoh CC and Swanson BG, Base catalyzed transesterification of vegetable oils, Journal of Food Processing \& Preservation 12: 139-149 (1988).

6. Ma F and Hanna MA, Biodiesel production: a review, Bioresource Technology 70: 1-15 (1999).

7. Fjerbaek L, Christensen KV and Norddahl B, A review of the current state of biodiesel production using enzymatic transesterification, Biotechnology and Bioengineering 102: 1298-1315 (2009).

8. Wang M, Nie K, Yun F, Cao H, Deng L and Wang F, Biodiesel with low temperature properties: Enzymatic synthesis of fusel alcohol fatty acid ester in a solvent free system, Renewable Energy 83: 1020-1025 (2015).

9. Du W, Li W, Sun T, Chen X and Liu D, Perspectives for biotechnological production of biodiesel and impacts, Applied Microbiology Biotechnology 79: 331-337 (2008).

10. Adamczak M, Bornscheuer UT and Bednarski W, The application of biotechnological methods for the synthesis of biodiesel, European Journal of Lipid Science and Technology 111: $800-813$ (2009).

11. Mendina AR, Moreno PAG, Cerdan LE and Grima EM, Biocatalysts: towards ever greener biodiesel production, Biotechnology Advances 27: 398-408 (2009).

12. Zhao X, Qi F, Yuan C, Du W and Liu D, Lipase-catalyzed process for biodiesel production: enzyme immobilization, process simulation and optimization, Renewable and Sustainable Energy Reviews 44: 182-197 (2015). 
13. Jensen MØ, Jensen TR, Kjaer K, Bjørnholm T, Mouritsen OG and Peters GH, Orientation and conformation of a lipase at an interface studied by molecular dynamics simulations, Biophysical Journal 83: 98-111 (2002).

14. Ren H, Du W, Lv L and Liu D, Study on free lipase-catalyzed ethanolysis for biodiesel preparation in an oil/water biphasic system, Journal of the American Oil Chemist's Society 88: 1551-1555 (2011).

15. Li Y, Du Wei and Liu D, Free lipase-catalyzed biodiesel production from phospholipids-containing oils, Biomass and Bioenergy 71: 162-169 (2014).

16. Nordblad M, Silva VTL, Nielsen PM and Woodley JM, Identification of critical parameters in liquid enzyme-catalyzed biodiesel production, Biotechnology and Bioengineering 111: 2446-2453 (2014).

17. Li L, Du W, Liu D, Wang L and Li Z, Lipase-catalyzed transesterification of rapeseed oils for biodiesel production with a novel organic solvent as the reaction medium, Journal of Molecular Catalysis B: Enzymatic 43: 58-62 (2006).

18. Nielsen PM, Brask $\mathrm{J}$ and Fjerbaek L, Enzymatic biodiesel production: technical and economical considerations, European Journal of Lipid Science Technology 110: 692-700 (2008).

19. Pedersen AT, Nordblad M, Nielsen PM and Woodley JM, Batch production of FAEE-biodiesel using a liquid lipase formulation, Journal of Molecular Catalysis B: Enzymatic 105: 89-94 (2014). 
20. Colucci J, Borrero E and Alape F, Biodiesel from an alkaline transesterification reaction of soybean oil using ultrasonic mixing, Journal of the American Oil Chemists' Society 82: 525-530 (2005).

21. Hanh HD, Dong NT, Starbarcache C, Okitsu K, Maeda Y and Nishimura R, Methanolysis of triolein by low frequency ultrasonic irradiation, Energy Conversion \& Management 49: $276-280$ (2008).

22. Hanh HD, Dong NT, Okitsu K, Nishimura R and Maeda Y, Biodiesel production by esterification of oleic acid with short-chain alcohols under ultrasonic irradiation condition, Renewable Energy 34: 780-783 (2009).

23. Hsiao MC, Lin CC, Chang YH and Chen LC, Ultrasonically driven continuous process for vegetable oil transesterification of soybean oil, Fuel 89: 3618-3622 (2010).

24. Zhang DN, Guo XY, Yang QH, Chen ZG and Tao LJ, An efficient enzymatic modification of cordycepin in ionic liquids under ultrasonic irradiation, Ultrasonics Sonochemistry 21: $1682-1687$ (2014).

25. Waghmare G, Vetal MD and Rathod VK, Ultrasound assisted enzyme catalyzed synthesis of glycerol carbonate from glycerol and dimethyl carbonate, Ultrasonics Sonochemistry 22: 311-316 (2015)

26. Gogate PR, Wilhelm AM and Pandit AB, Some aspects of the design of sonochemical reactors, Ultrasonics Sonochemistry 10: 325-330 (2003). 
27. Gogate PR, Sutkar VS and Pandit AB, Sonochemical reactors: important design and scale up considerations with a special emphasis on heterogeneous system, Chemical Engineering Journal 166: 1066-1082 (2011).

28. Neppiras EA, Acoustic cavitation, Physics Reports 3:159-251(1980).

29. Sutkar VS and Gogate PR, Design aspects of sonochemical reactors: techniques for understanding cavitational activity distribution and effect of operating parameters, Chemical Engineering Journal 155: 26-36 (2009).

30. Michelin S, Penha FM, Sychoski MM, Scherer RP, Treichel H, Valerio A, Luccio MD, Oliveira D and Oliveira JV, Kinetics of ultrasound-assisted enzymatic biodiesel production from Macauba coconut oil, Renewable Energy 76: 388-393 (2015).

31. Gharat N and Rathod VK, Ultrasound assisted enzyme catalyzed transesterification of waste cooling oil with dimethyl carbonate, Ultrasonics Sonochemistry 20: 900-905 (2013).

32. Tupufia SC, Jeon YJ, Marquis C, Adesina AA, and Rogers PL, Enzymatic conversion of coconut oil for biodiesel production, Fuel Processing Technology 106: 721-726 (2013).

33. Batistella L, Lerin LA, Brugnerotto P, Danielli AJ, Trentin CM, Popiolski A, Treichel H, Oliveira V and Oliveira D, Ultrasonics Sonochemistry 19: 452-458 (2012).

34. Kumar G, Kumar D, Poonam, Johari R and Singh CP, Enzymatic transesterification of Jatropha curcas oil assisted by ultrasonication, Ultrasonics Sonochemistry 18: 923-927 (2011).

This article is protected by copyright. All rights reserved. 
35. Fiametti KG, Sychoski MM, Cesaro AD, Furigo Jr A, Bretanha LC, Pereira CMP, Treichel H, Oliveira D and Oliveira JV, Ultrasound irradiation promoted efficient solvent-free lipase-catalyzed production of mono- and diacylglycerols from olive oil, Ultrasonics Sonochemistry 18: 981-987 (2011).

36. Marinelle M, Holmquist M and Hult K, On the interfacial activation of Candida antarctica lipase A and B as compared with Humicola lanuginosa lipase, Biochimica et Biophysica Acta 1258: 272-2276 (1995).

37. Bradley M, Ashokkumar and M, Grieser F, Sonochemical Production of Fluorescent and Phosphorescent Latex Particles, Journal of the American Chemical Society 125: 525-529 (2003).

38. Adewale P, Dumont MJ and Ngadi M, Enzyme-catalyzed synthesis and kinetics of ultrasonic-assisted biodiesel production from waste tallow, Ultrasonics Sonochemistry 27: 1-9 (2015).

39. Subhedar PB, Botelho C, Riberio A, Castro R, Pereira MA, Gogate PR and Paulo AC, Ultrasound intensification suppresses the need of methanol excess during the biodiesel production with Lipozyme TL-IM, Ultrasonics Sonochemistry 27: 530-535 (2015).

40. Zhu K, Liu H, Han P and Wei P, Study of ultrasound-promoted, lipase-catalyzed synthesis of fructose ester. Frontiers of Chemical Engineering in China 4: 367-371 (2010).

41. Wang JX and Huang OD, Lipase-catalyzed production of biodiesel from high acid value waste oil using ultrasonic assistant, Chinese Journal of Biotechnology 23: 1121-1128 (2007). 
42. Povedano MMD and Castro MDL, A review on enzyme and ultrasound: A controversial but fruitful relationship, Analytica Chimica Acta 889: 1-21 (2015).

43. Subhedar PB and Gogate PR, Ultrasound assisted intensification of biodiesel production using enzymatic interesterification, Ultrasonics Sonochemistry 29: 67-75 (2016).

44. Basto C, Silva CJ, Gubitz G and Paulo AC, Stability and decolourization ability of Trametes villosa laccase in liquid ultrasonic fields, Ultrasonics Sonochemistry 14: 355-362 (2007).

45. Subhedar PB and Gogate PR, Enhancing the activity of cellulase enzyme using ultrasonic irradiations, Journal of Molecular Catalysis B: Enzymatic 101: 108-114 (2014).

46. Kadkhodaee R and Povey MJW, Ultrasonic inactivation of Bacillus $\alpha$-amylase. I. effect of gas content and emitting face of probe, Ultrasonics Sonochemistry 15: 133-142 (2008).

47. Ozbek B and Ulgen KO, The stability of enzymes after sonication, Process Biochemistry 35: 1037-1043 (2000).

48. Coakley WT, Brown RC and James CJ, The inactivation of Enzyme by ultrasonic cavitation at 20kHz, Archives of biochemistry and biophysics 159: $722-729$ (1973).

49. Vercet A, Burgos J,Crelier S and Buesa PL, Inactivation of protease and lipase by ultrasound, Innovative Food Science \& Emerging Technologies 2: 139-150 (2001).

50. Gumel AM, Annuar MSM and Chisti Y, Lipase catalyzed ultrasonic synthesis of poly-4hydroxybutyrate-co-6-hydroxyhexanoate, Ultrasonics Sonochemistry 20: 937-947 (2013).

This article is protected by copyright. All rights reserved. 
51. Talukder MMR, Zaman MM, Wu JC and Kawanishi T, Ultrasonification enhanced hydrolytic activity of lipase in water/isooctane tow phase systems, Biocatalysis and Biotransformation 24: 189-194 (2006).

52. Ha SH, Hiep NM and Koo Y, Enhanced production of fructose palmitate by lipase-catalyzed esterification in ionic liquids, Biotechnology and Bioprocess Engineering 15: $126-130(2010)$.

53. Yu D, Tian L, Wu H, Wang S, Wang Y, Ma D and Fang X, Ultrasonic irradiation with vibration production from soybean oil by Novozym 435, Process Biochemistry 45: 519-525 (2010). 


\title{
Caption of Figures
}

\author{
Figure 1 Consecutive reaction processes for fatty acid methyl ester (FAME) \\ production by lipase with alcohol.
}

Figure 2 Schematic diagram of the circulation two-compartment reactor.

Figure 3 Change of mass fraction of components of transesterification reactions.

(a) TAG. (b) DAG. (c) MAG. (d) FAME.

Figure 4 Reaction enhancement of ultrasound irradiation on FAME production with ultrasound irradiation in US compartment (38W). Enzyme concentration was set at 0.09 [g-enzyme $\mathrm{g}^{-1}-($ enzyme + water $\left.)\right]$.

Figure 5 Hanes-Woolf plot for reaction parameters FAME production by soluble lipase (Callera $\mathrm{L}^{\mathrm{TM}}$ ) donated by Novozymes A/S (Bagsværd, Denmark). Substrate was a rapeseed oil obtained from Emmelev A/S (Otterup, Denmark).

Figure 6 Effect of ultrasound power on initial reaction rate involved with mean 
residence time in the US compartment.

Figure 7 Different mean residence time in the US compartment of reaction fluid. (a) Periodic longer intermittent residence in the US. Ultrasonic irradiation to enzyme caused unexpected damage of enzyme. Enzyme hardly recovered its reactivity. (b) Periodic shorter intermittent residence in the US. Damage of enzyme by short ultrasonic irradiation was quickly recovered during isolated period in the ST just after exposure in the US.

Figure 8 Lipase productivity on FAME at $24 \mathrm{~h}$ enhanced by ultrasonic irradiation.

Figure 9 Effect of space velocity in the US compartment on initial reaction rate under the ultrasound power $38 \mathrm{~W}$. Initial reaction rate was remarkably improved in higher space velocity in the US compartment.

Figure 10 Logarithmic correlation of initial reaction rate and ultrasound energy employed. Higher initial reaction rate was successfully attained in higher space velocity consisted with minimalized enzyme damage in US compartment even if high irradiation energy of ultrasound. 


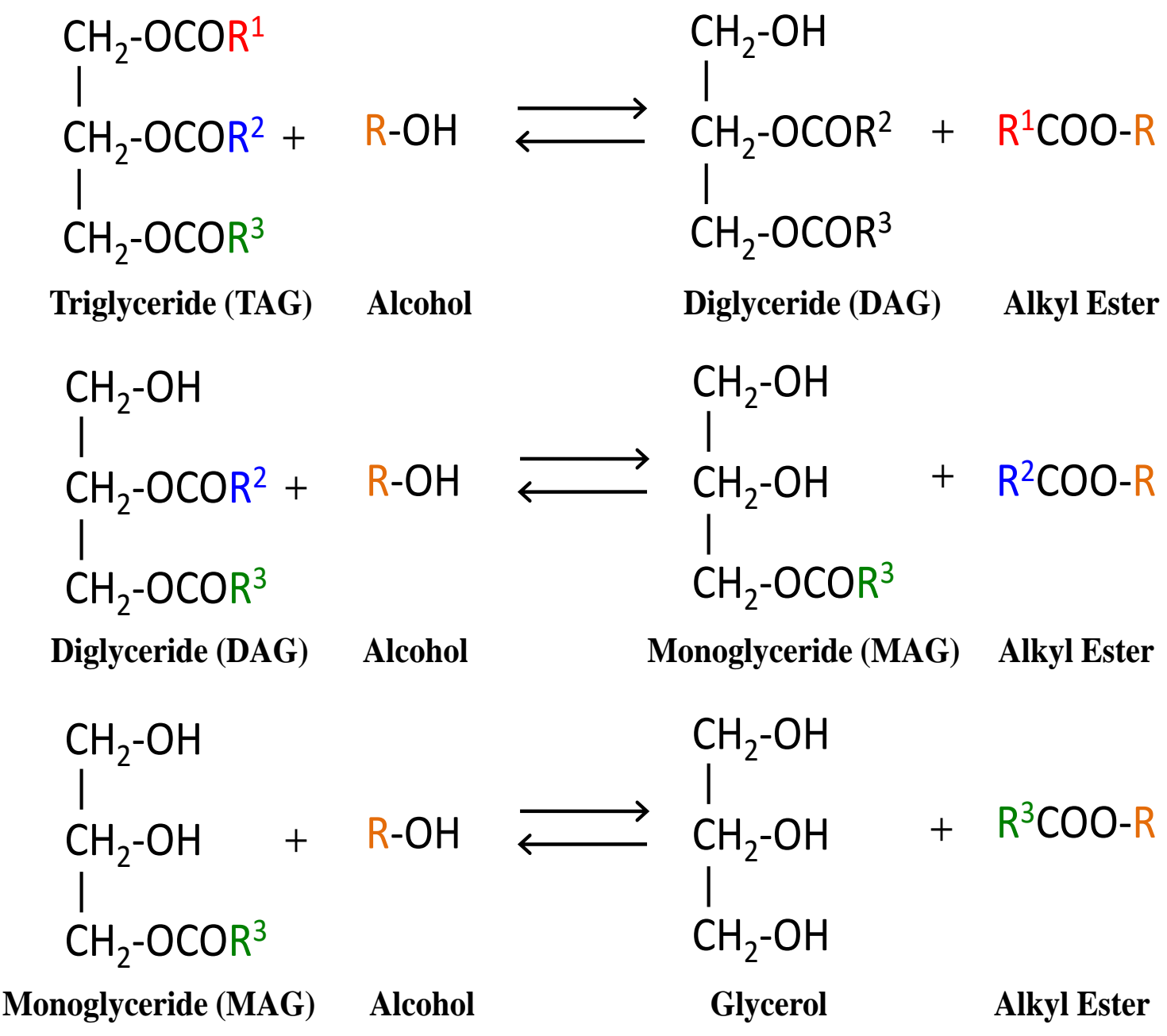

\section{Figure 1 1 protected by copy Nakayama et al. (2016)}







(a)

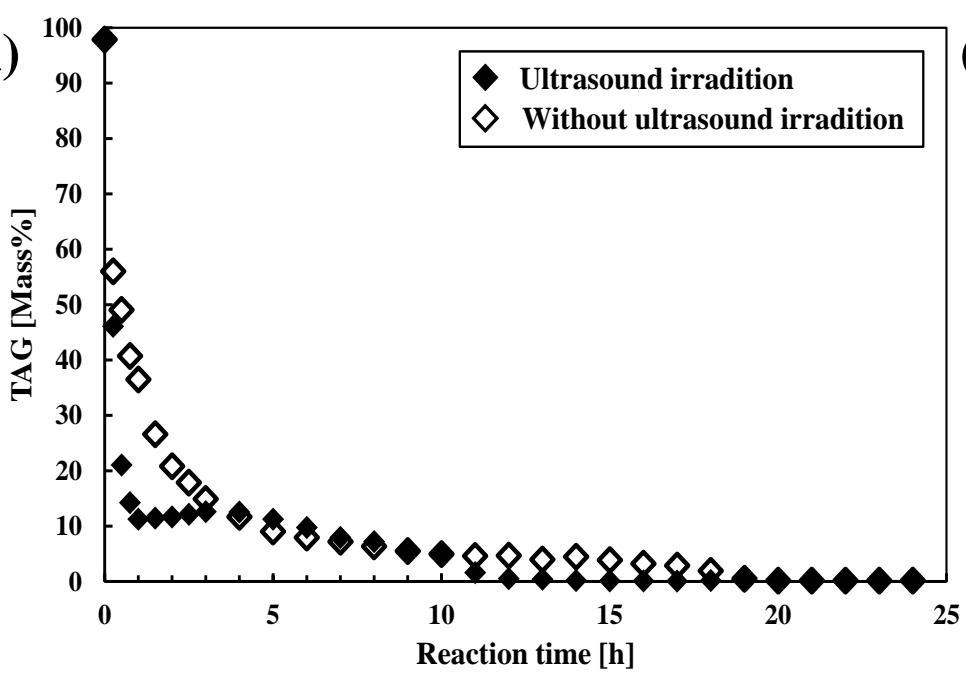

(c)

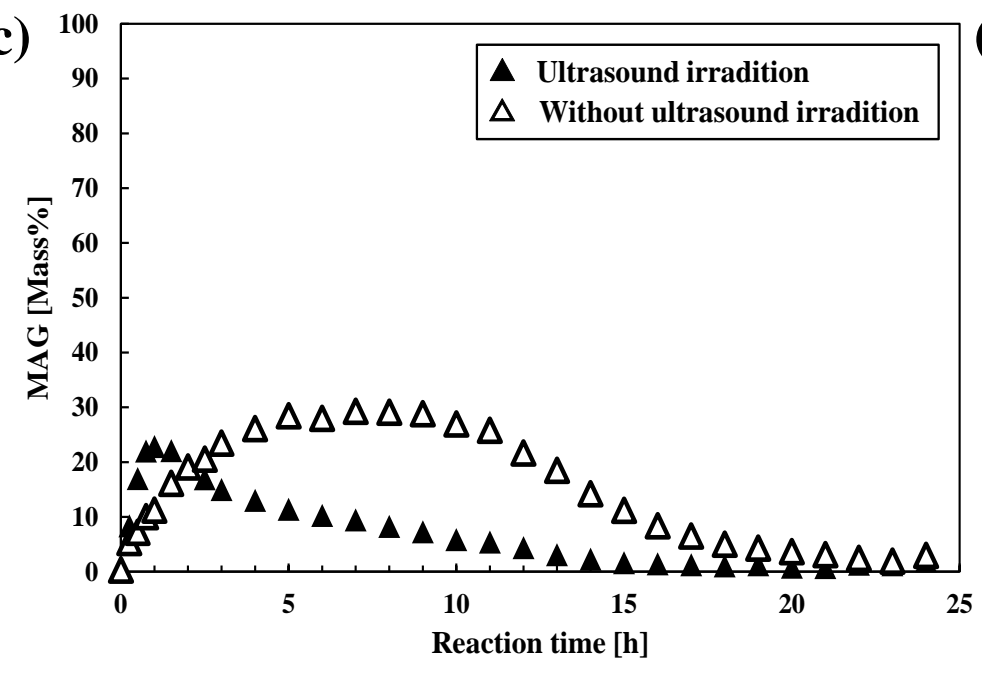

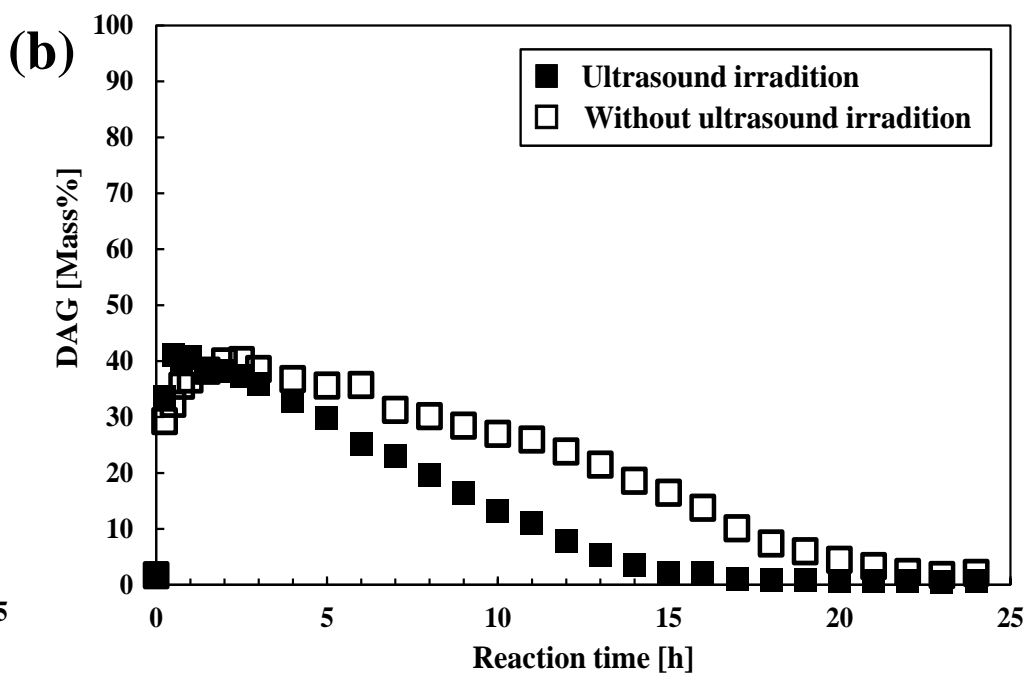

(d)

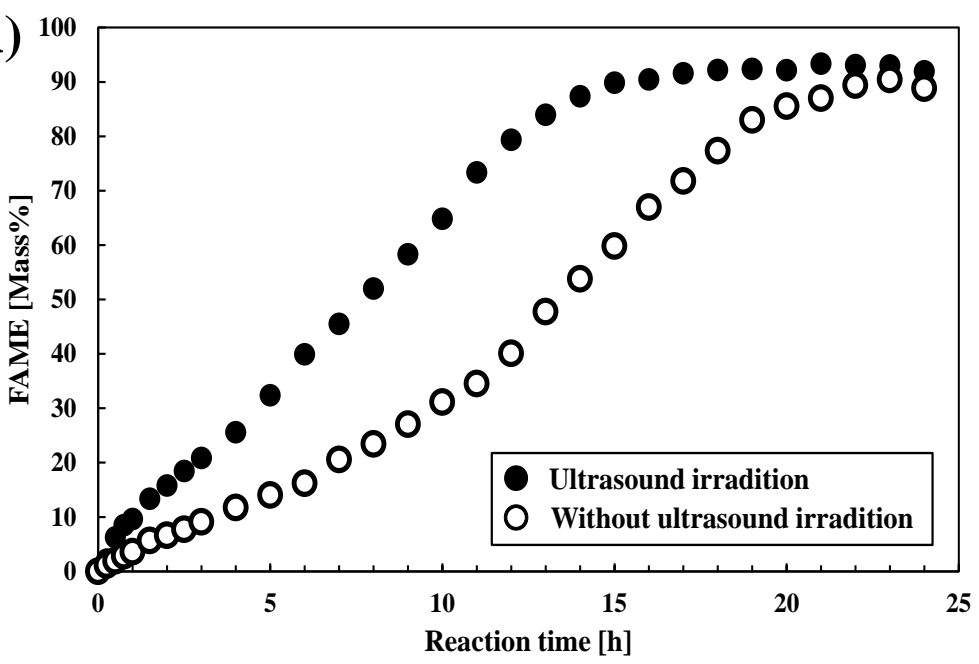

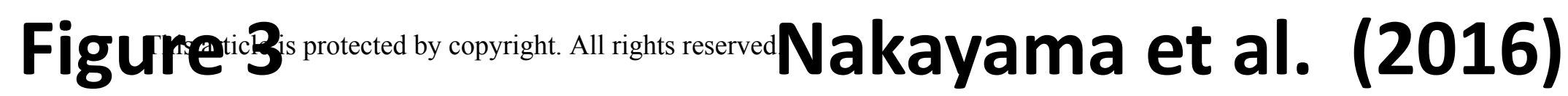




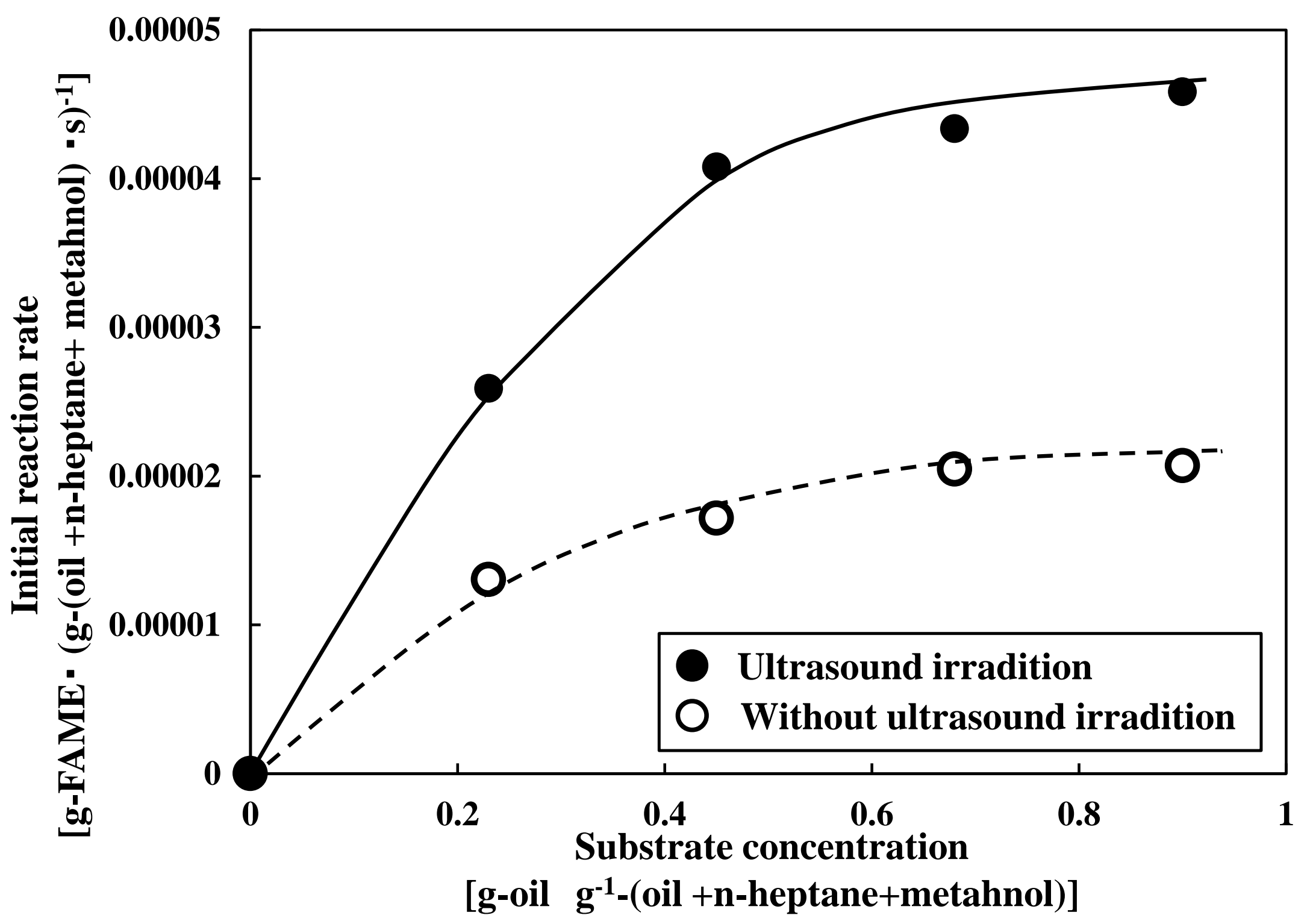

Figure 4 protected by coppright All right resereced Nakayama et al. (2016) 


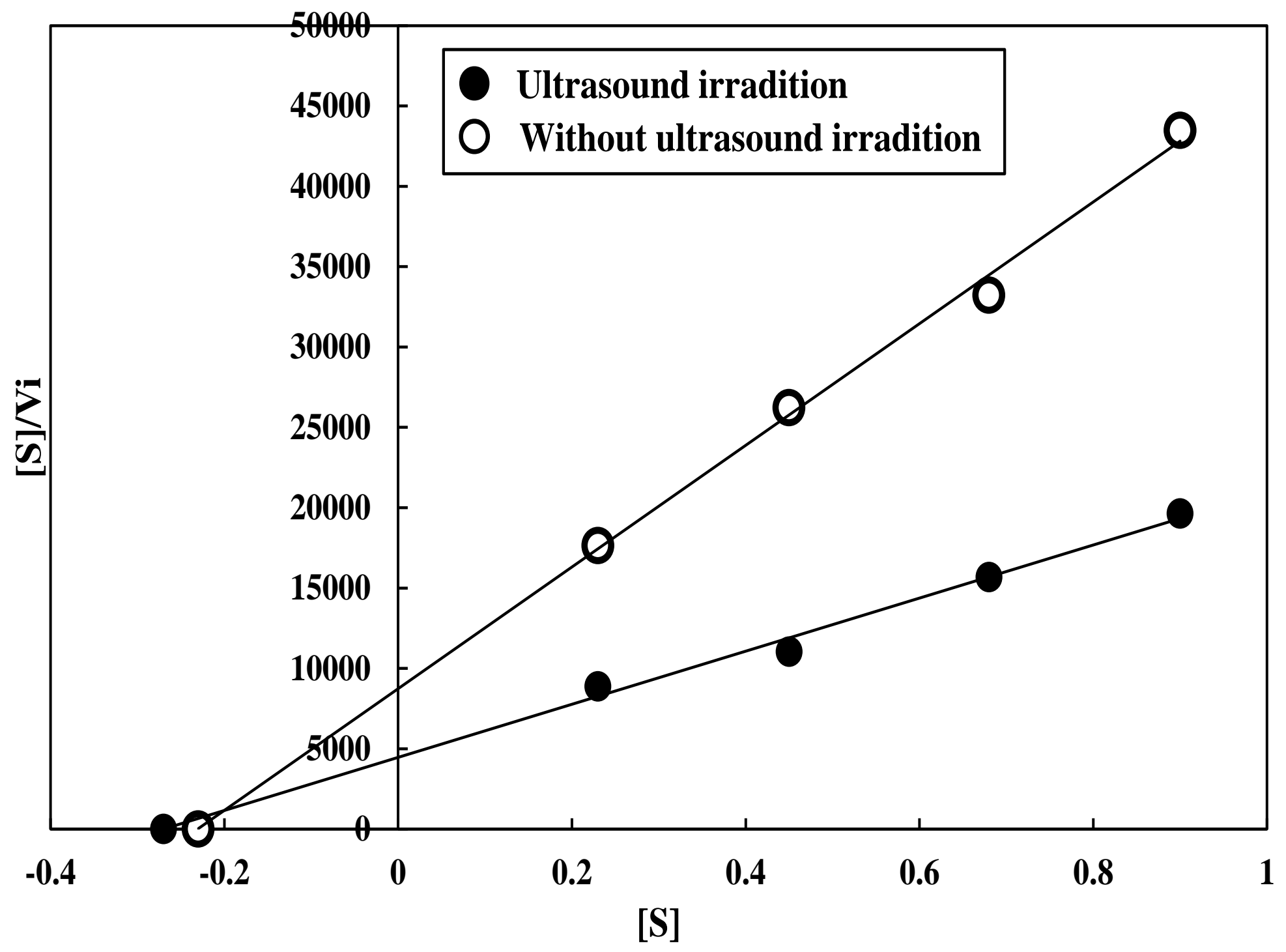

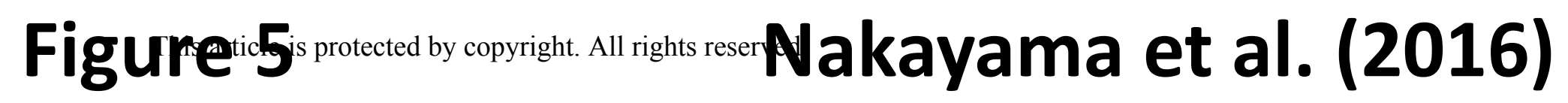




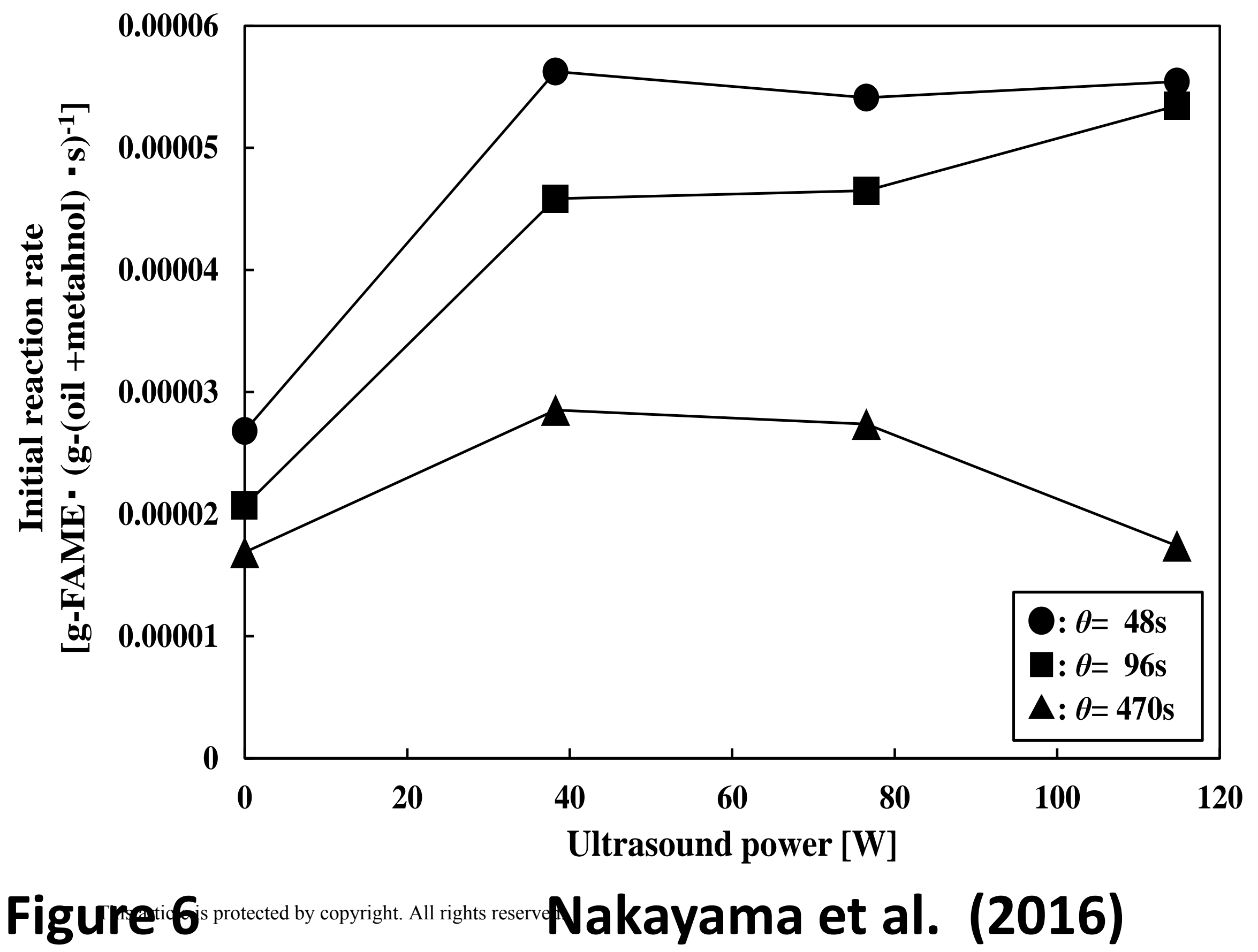


US irradiation US irradiation US irradiation

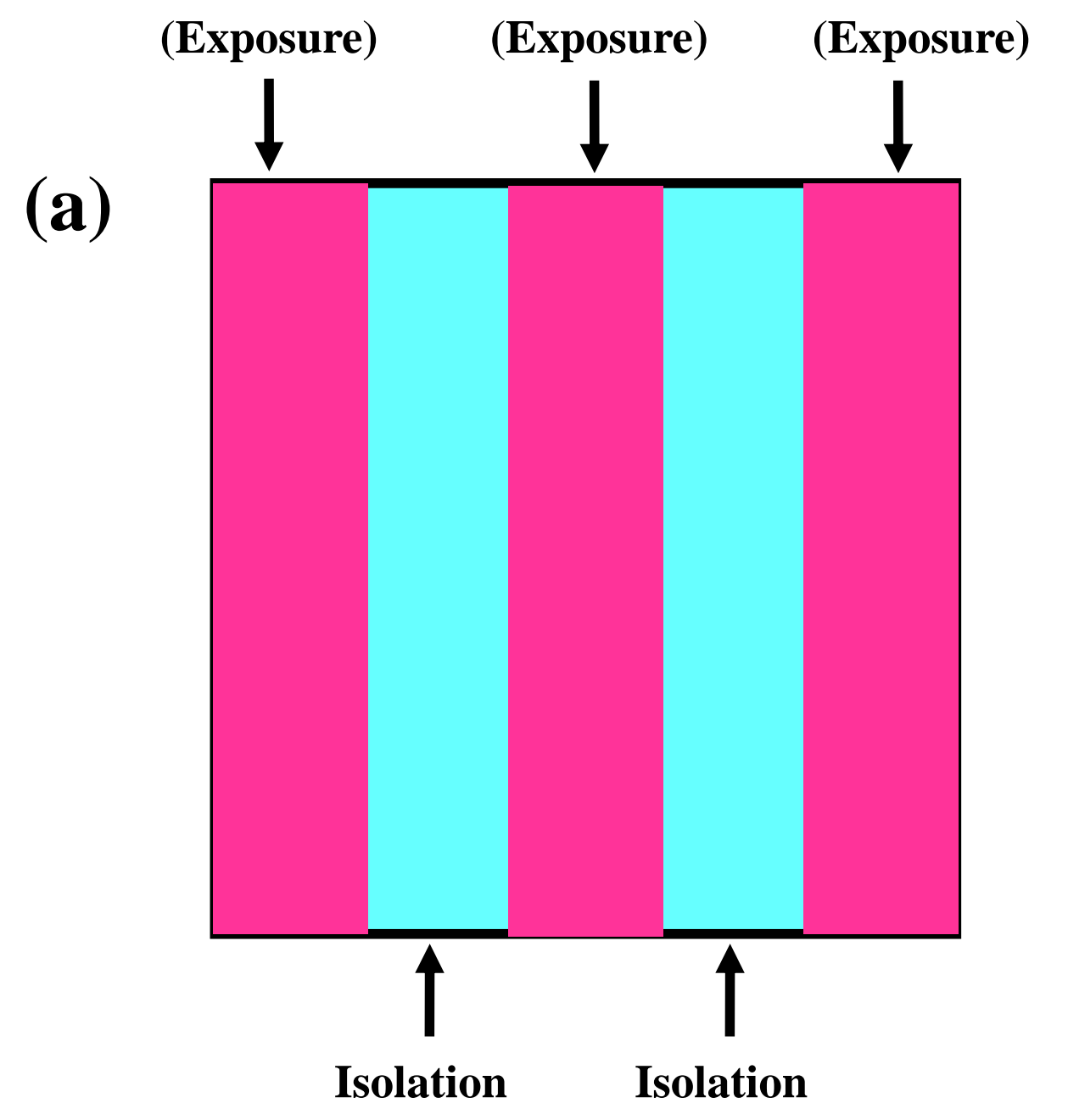

(b)

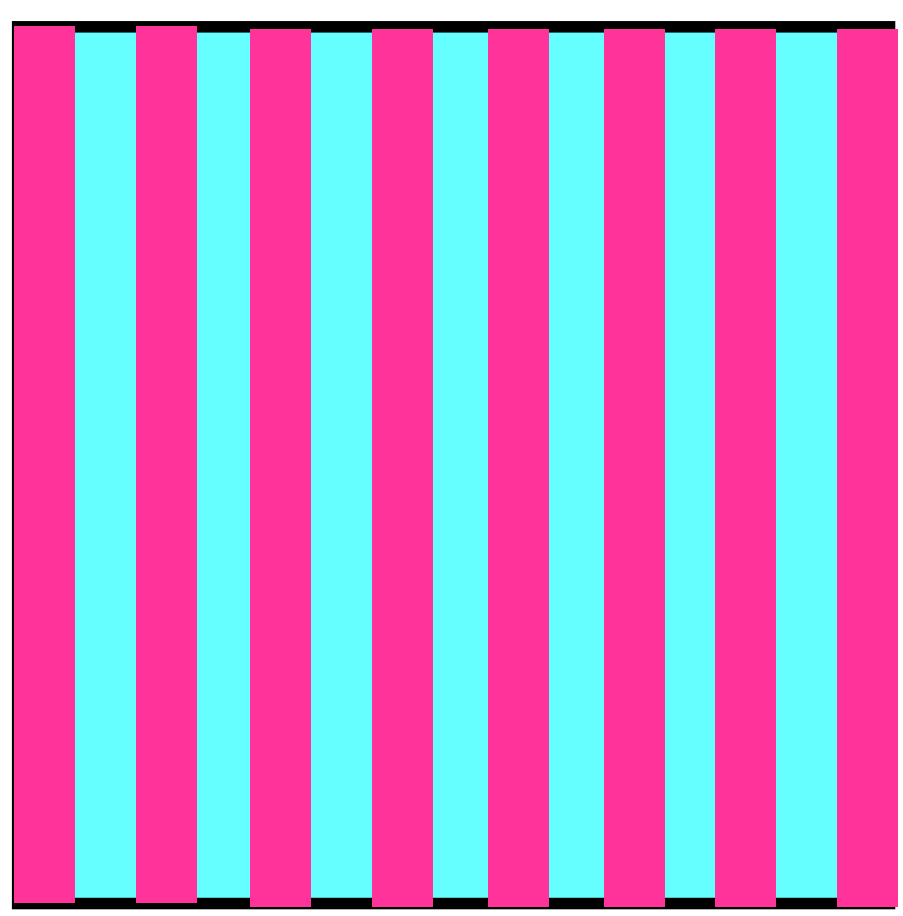

Isolation Isolation 


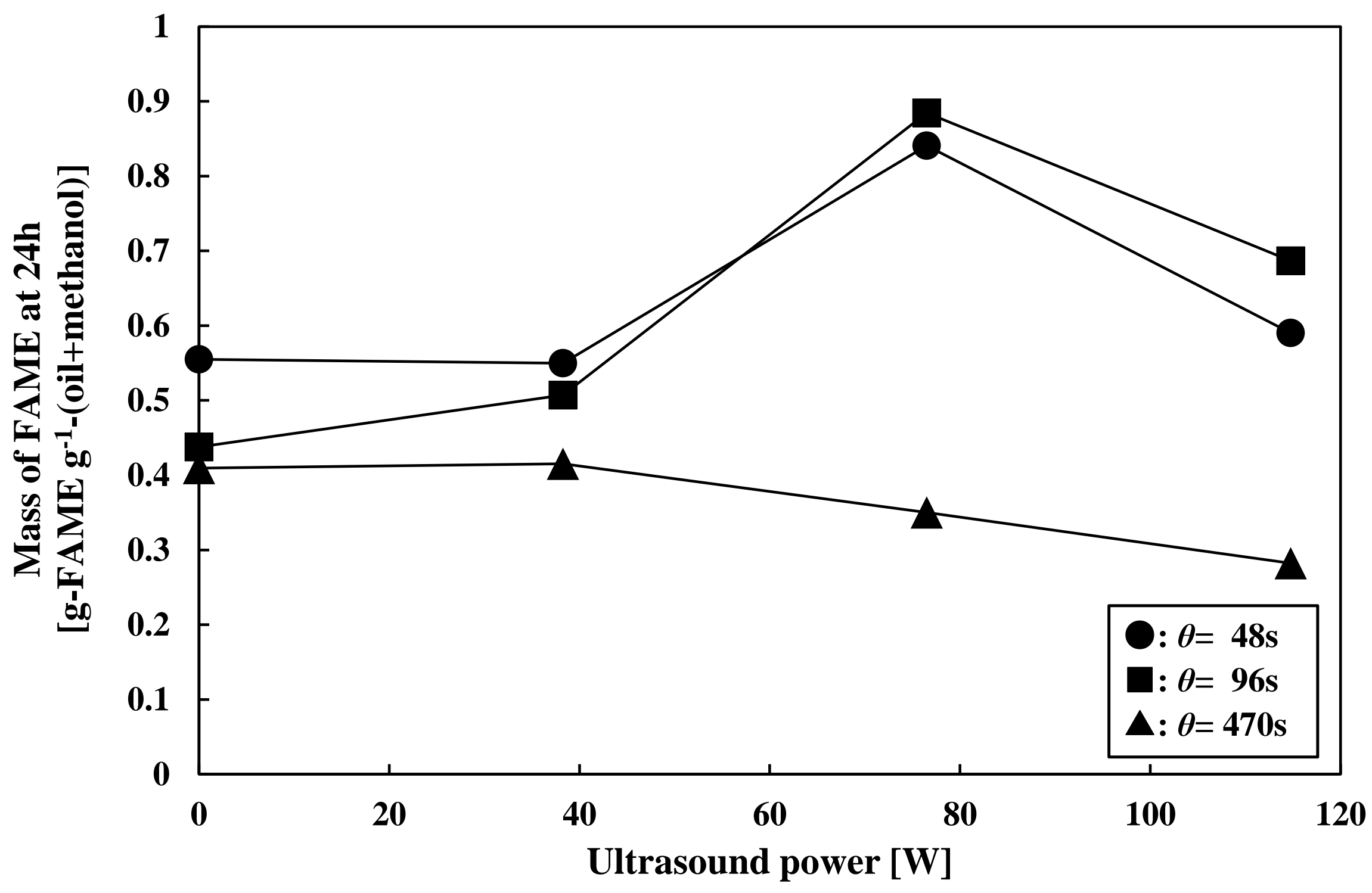

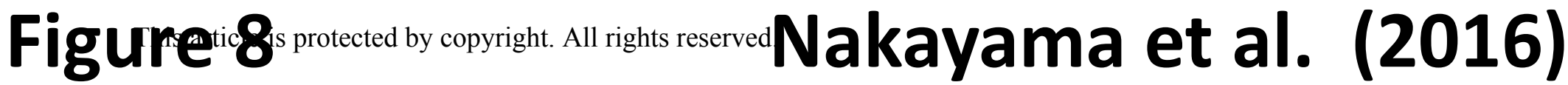




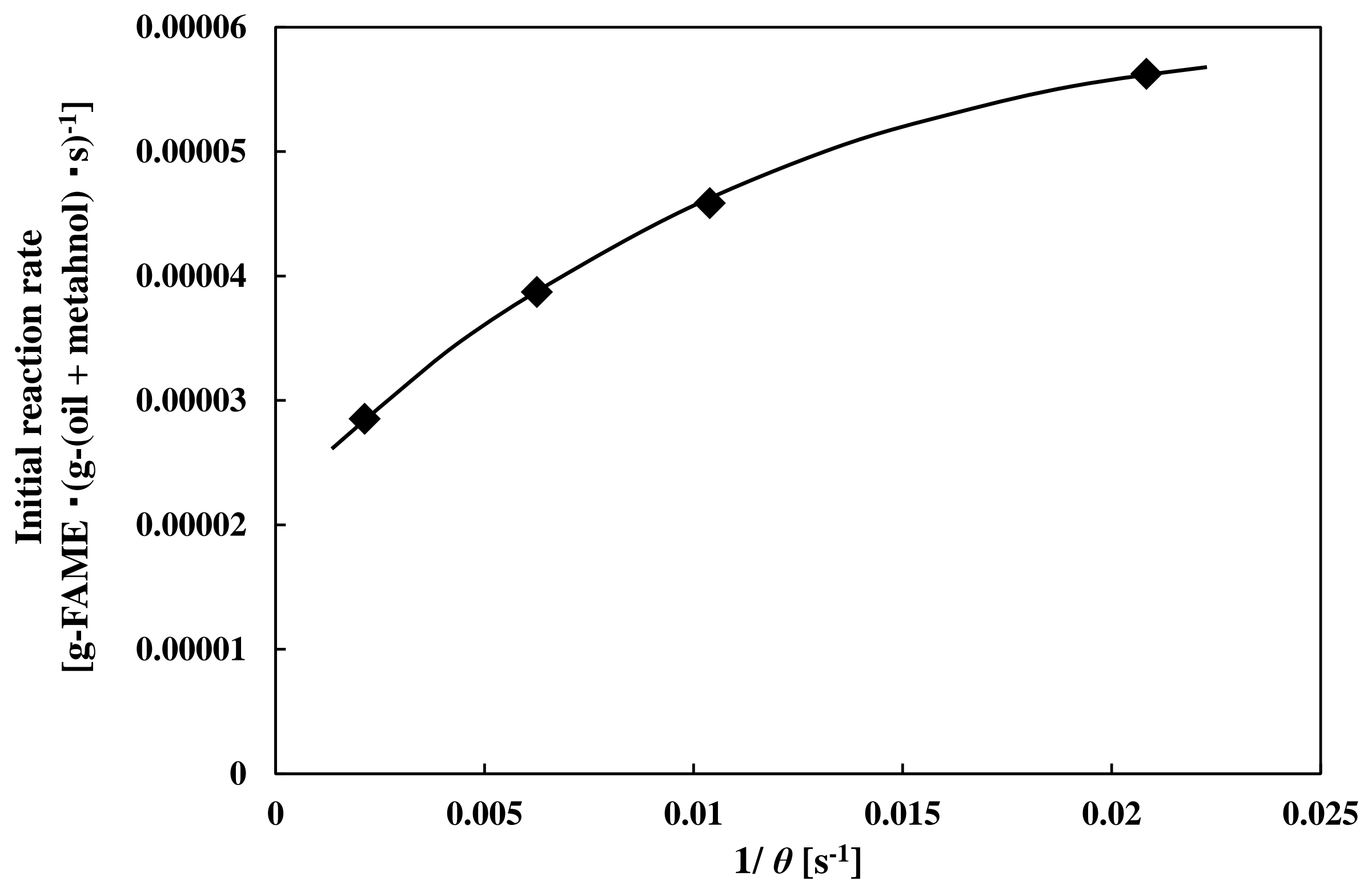

Figure ${ }^{\text {a }}$ s rotected by copyright. All rights reserv Nakayama et al. (2016) 
Table 1 Previous articles for production of biodiesel from natural resources with ultrasound irradiation.

\begin{tabular}{|c|c|c|c|c|c|c|c|c|}
\hline Author & Year & Ultrasound reactor type & Ultrasound power [W] / frequency [KHzz] & Feedsiock & Catalyst & Solvent & Yield & Reterence \\
\hline Subhedar, P.B. and Gogate P.F & 2016 & Direct (hom) & 80W / 20kHz & Waste cooking oil & Enzyme (Lpozzme RMMM) & Methyl aceitate & $96.1 \%$ & [43] \\
\hline Adewale, P. etal. & 2015 & Direct (hom) & 500W/200k Hz & Wastetallow & Enzyme (Candida annatcicica lipaseB) & Methanol & $85.6 \%$ & [38] \\
\hline Subhedar, P.B. etal. & 2015 & Indirect (bath) & 120W/455 Hz & Sunflower oll & Enzyme (Lipozyme RMMM) & Methanol & $96 \%$ & [39] \\
\hline Mchelin, S. ettal. & 2015 & Indirect (bath) & 132W/ $/ 40 \mathrm{KH}$ & Nacaabac coconutiol & | Enzyme (Novozyme 435) & Ethanol & $70 \%$ & [30] \\
\hline Gharat, N. and Rathod, V.K. & 2013 & Indirect (bath) & $200 \mathrm{~W} / 25 \mathrm{kHz}$ & Waste cooking oll & Enzyme (Novozyme 435) & Methanol & $87 \%$ & [31] \\
\hline Tuputia, S.Cet tal. & 2013 & Indirect (bath) & 8ON/ $433 \mathrm{~K} / 2$ & Cocontiol & Enzyme (Novozmme 435) & Ethanol & $91 \%$ & [32] \\
\hline Bailistella, L. etal. & 2012 & Indirect (bath) & $100 \mathrm{~W} / 37 \mathrm{kHz}$ & Soybean oil & Enzyme Novozyme 435, Lipozyme RMIM) & Ethanol & $90 \%$ & [33] \\
\hline Kumar, G. etal. & 2011 & Direct (horn) & $100 \mathrm{~W} / 24 \mathrm{kHz}$ & Jatroohacurcas oil & Enzyme (immobilized lipasetrom Enterobaccer aerogenes) & Methanol & $84.5 \%$ & [34] \\
\hline Yu, Detal. & 2010 & Indirect (bath) & 250W/40KHz & Soybean oil & Enzyme (Novozmme 435) & Methanol & $96 \%$ & [53] \\
\hline
\end{tabular}


Table 2 Typical component of refined rapeseed oil.

\begin{tabular}{ll|c}
\hline \multicolumn{2}{c|}{ Properties } & Refined rapeseed oil [\%] \\
\hline \hline Myristic acid & C14:0 & 0.1 \\
\hline Palmitic acid & C16:0 & 4.8 \\
\hline Palmitoleic acid & C16:1 & 0.3 \\
\hline Stearic acid & C18:0 & 1.8 \\
\hline Oleic acid & C18:1 & 63.7 \\
\hline Linoleic acid & C18:2 & 18.8 \\
\hline Linolenic acid & C18:3 & 7.9 \\
\hline Arachidic acid & C20:0 & 0.6 \\
\hline Gadoleic acid & C20:1 & 1.1 \\
\hline Behenic acid & C22:0 & 0.3 \\
\hline Erucic acid & C22:1 & 0.1 \\
\hline
\end{tabular}


Table 3 Details of recirculation conditions in the two-compartment reactor.

\begin{tabular}{|c|c|c|c|c|c|c|}
\hline Volume of US: $V_{U}[\mathrm{~mL}]$ & Volume of ST: $V_{S}[\mathrm{~mL}]$ & $\begin{array}{l}\text { Volume of connected recirculation } \\
\text { loop between } S T \text { and US: } V_{L}[\mathrm{~mL}]\end{array}$ & Flow rate: $F\left[\mathrm{~mL} \mathrm{~s}^{-1}\right]$ & Mean residence time in US: $\theta[\mathrm{s}]$ & $\begin{array}{l}\text { Overall circulation time of } \\
\text { reaction line: } \theta[s]\end{array}$ & $\theta / \theta[-]$ \\
\hline \multirow{4}{*}{80} & \multirow{4}{*}{267} & \multirow{4}{*}{40} & 0.17 & 470 & 2276 & 0.21 \\
\hline & & & 0.50 & 160 & 774 & 0.21 \\
\hline & & & 0.83 & 96 & 466 & 0.21 \\
\hline & & & 1.67 & 48 & 231 & 0.21 \\
\hline
\end{tabular}

$\theta=\frac{V_{U}}{F} \quad \Theta=\frac{V_{U}+V_{S}+V_{L}}{F}$ 
Table 4 Properties of rapeseed oil.

\begin{tabular}{c|c|c}
\hline & Molecular Weight & Density $\left[\mathrm{kg} \mathrm{m}^{-3}\right]$ \\
\hline FAME & 295 & - \\
\hline FFA & 282 & 895 \\
\hline TAG & 881 & 920 \\
\hline DAG & 618 & - \\
\hline MAG & 355 & - \\
\hline Rapeseed oil & - & 910 \\
\hline
\end{tabular}


Table 5 Kinetic parameters of transesterification of rapeseed oil in two-compartment reactor.

Ultrasound irradiation

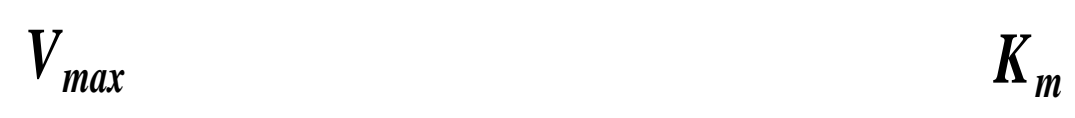

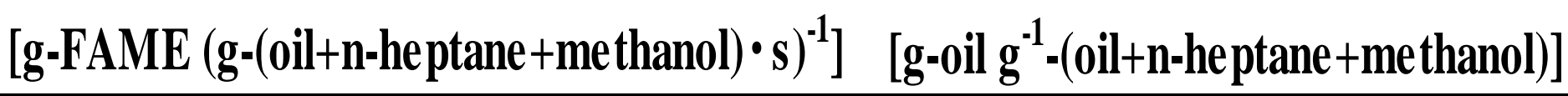

\begin{tabular}{cll}
\hline Free & $2.65 \times 10^{-5}$ & 0.23 \\
\hline $38 \mathrm{~W}$ & $6.07 \times 10^{-5}$ & 0.27 \\
\hline
\end{tabular}






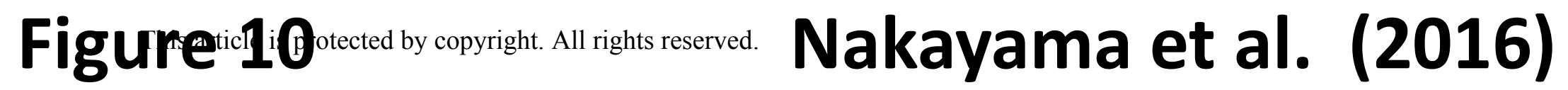

